\title{
THE COMMON LAW AS CENTRAL ECONOMIC PLANNING*
}

\author{
Peter H. Aranson**
}

Central economic planning traditionally has set goals and allocated resources by supplanting the price system with central direction. Planners engaged in industry-by-industry and firm-by-firm decision making, all to achieve predetermined targets. The neoclassical approach to law and economics posits that common law judges engage in a similar activity, in rendering decisions that maximize wealth. A significant feature of this approach is the placement of judges in the position of calculators of comparative values. Neither advocates of central planning nor those of judicial wealth maximizing address or solve the economic calculation problem. The various aspects of that problem hold two implications for common law judges. First, they cannot accomplish the tasks that the neoclassical approach sets out for them. Second, a recognition of the calculation problem leads to a rejection of balancing and the choice of rights-based, bright-line rules that return actual and potential litigants' decisions to the market.

\section{Introduction}

I argue here that explanatory and normative applications of neoclassical microeconomic theory to the common law fail to address the economic calculation problem. This is the same criticism that Austrian economic theorists and writers of the London School of Economics (L.S.E.) on subjective opportunity cost have aimed at theoretical justifications for central economic planning. Although central planning and common law judging are not identical activities, neoclassical and

*An earlier version of this essay was prepared for a Liberty Fund, Inc., Conference on "The Problems of Economic Calculation under Socialism," New York City, January 26-27, 1986. Some time after the completion of the $1986 \mathrm{draft}$, I received working papers from Louis De Alessi and Bob Staaf. They were pursuing the same themes that this paper explores, but in a more focused manner. 1 gained greatly from their work, for it gave me confidence that these ideas are worth pursuing. I thought it appropriate to revisit this paper for a volume in Bob Staaf's memory. I have also benefitted greatly from extended discussions with Andrew Kull and Paul Rubin.

**Professor of Economics and Chair, Department of Economics, Emory University, Atlanta, GA 30322. 
normative propositions concerning both activities remain subject to the same criticisms.'

Section I reviews the central model and arguments about common law efficiency, and Section II examines Austrian and L.S.E. critiques of the calculation problem in the context of central planning. Section III interprets Rubin's (1977) tort model in light of the calculation problem and then explores in a similar manner certain features of contract and property law. Section IV then explores the implications of the calculation problem for the choice of legal rules.

This discussion attends principally to how well various legal rules fare in light of the calculation problem. I purposely suppress a review of the rules' comparative merits on neoclassical grounds. It turns out that many alternative rules (for example, negligence versus strict liability) may (Brown 1973) or may not (Shavell 1980) be equally efficient under the usual assumptions. I also do not explore questions of strategic actions, as these ordinarily form poorly considered makeweight arguments. $^{2}$

\section{Theories of Common Law Efficiency}

\section{Background to the Controversy}

The line of research from Coase's "The Problem of Social Cost" (1960), to Posner's first edition of Economic Analysis of Law (1972b), to Rubin's "Why is the Common Law Efficient?" (1977) prompted a curiosity that subsequent attacks on law and economics from the left have tended to obscure. Scholars of the post-Simons Chicago School had discovered a public-sector institution that, apparently, tended to adopt welfare-regarding, efficiency-enhancing rules. ${ }^{3}$

I One could argue that judging and planning share common characteristics, especially in light of contemporary neoclassical interpretations of the common law. But such a comparison would be strained. The comparison offered here concerns less the actual activities of judging and planning and more the neoclassical intellectual structures that model each activity.

2 See, e.g., Cooter and Ulen 1988: 293-96, on the ill-conceived nature of arguments against specific performance as a remedy for breach of contract, based on predictions of strategic action.

3 It remains impossible to sustain the claim that Chicago School economists never met a form of government intervention they liked. See, e.g., McChesney 1991. So the characterization to the contrary is overdrawn. 
Enthusiasm for the common law derived from three very different traditions. First, interpreted in neoclassical construct, the early evidence seemed compelling that common law rules induced allocatively efficient actions in the private sector (Posner 1972a, 1972b, 1977). Hence, the common law process contrasted sharply and favorably with that of legislation or administrative regulation, which act on distributiona margins, to induce inefficient resource allocations (Tullock 1967; Stigler 1971; Posner 1971, 1974; Peltzman 1976; Aranson and Ordeshook 1981). ${ }^{4}$

Second, interpreted in an Austrian construct, the Rubin and Priest (1977) models gave indirect evidence of a rivalrous, entrepreneurial legal process, evolutionary in character, in which the decision to sue or settle rests on individual (disequilibrium) margins of opportunity for gain (or avoidance of loss). That is, one could not distinguish readily between the actions of litigants and their lawyers in these models of the common law process and those of market entrepreneurs in the analyses of Hayek (1945) and Kirzner (1973, 1979, 1985). Rubin, Priest, and others who followed in this line of research had made no such connections. But legal rivalry appeared to share efficiency-seeking properties with market rivalry, rather than the welfare-dissipating properties of political conflict.

Third, and from a rights-regarding construct not too distant from Austrian concerns, perhaps under the influence of Coase (1960), Demsetz $(1964,1967)$, and Rubin, the literature on common law efficiency seemed initially to be part of a larger economic theory of rights. Several writers understood early neoclassical works on common law efficiency to be saying that suits, and therefore changes in the law, could only arise if rights had not yet been (efficiently) defined, which would then create conflicting claims that courts eventually would get right. There was an implicit agreement to abide by the results of the legal process, so that even if courts occasionally might reassign rights in response to changing conditions and valuations, the associated redistributions would remain incidental, and the result, ex ante, would be efficient. More to the point, the common law process seemed appropriately to

4 Epstein (1982) argues that the choices among common law doctrines (e.g., strict liability versus negligence) give little opportunity for working allocative or distributive consequences. But legislation and administrative actions provide a superior means for accomplishing distributive consequences. 
go against the majoritarian grain of legislative hyperpluralism (Aranson and Ordeshook 1985; Lowi 1979), and to enshrine primordial rights, "legitimate expectations" (Aranson 1988; Leoni 1992), which the courts took it upon themselves only to discover.

Enthusiasm for the common law remains, but a deeper understanding of its process and substance, as well as an enhanced appreciation of limitations to the truth claims of the common law efficiency literature, have tempered that enthusiasm. Works by Rizzo (1980a, 1980b, 1985), Epstein (1973, 1979, 1980), O'Driscoll (1980), and others implicitly link the putative activities of (by postulation) efficiency-eeking common law judges to the socialist central-planning process. From there it is but a short step to apply the central Austrian and L.S.E. contributions to the economic calculation problem, to the claims of common law efficiency.

\section{The Coase Theorem}

The common law doubtless incorporates a strong economic content. Sometimes that content takes the form of such assertions, as Prosser's (1955: 398f., as quoted in Coase 1960: 19) repeating of an old nuisance doctrine in dog French, "Le utility del chose excusera le noisomness del stink." At other times it rises to the level of an explicit formulation, as in Chief Judge Leamed Hand's famous casting of the liability question in United States v. Carroll Towing Co. ${ }^{5}$

In spite of this economic content, until the publication of Coase's "The Problem of Social Cost" (1960) economists seldom recognized that the common law had allocative consequences. Before that date most social scientists viewed the common law "merely" as a dispute resolution mechanism, whose principal contribution to efficiency was

5 Judge Hand's opinion purports to calculate a level of care that would make a defendant a "reasonable man," thus releasing him from tort liability. It reads in pertinent part: "Since there are occasions when every vessel will break from her moorings, and since, if she does, she becomes a menace to those about her, the owner's duty, as in other similar situations, to provide against resulting injuries is a function of three variables: (1) the probability that she will break away; (2) the gravity of the resulting injury if she does; (3) the burden of adequate precautions. . . . [I]f the probability be P; the injury, $\mathrm{L}$; and the burden, B; liability depends upon whether B is less than $\mathrm{L}$ multiplied by $\mathrm{P}$ ..." United States v. Carroll Towing Co., 159 F.2d 169 (2nd Cir. 1947). For a criticism and reformulation of the Hand rule, see Brown 1973. For an earlier statement of the reasonable-man standard, see Blyth v. Birmingham Water Works, 11 Exch. 781 (1865). 
to reduce the wastefulness of self-help remedies. The common law concerned the province of rights, while economic analysis examined the province of preferences and costs. Economists' central publicsector concerns, then, remained with legislation and regulation.

Coase is the first economist (of whom I am aware) to ask explicitly whether common law rules-judges' decisions and resulting precedents-have allocative consequences. He wrote specifically about nuisance law, but his work enjoys far broader application. The Coase Theorem is well known; I briefly rehearse it here to isolate points of contention that arise later within the structure of the calculation problem.

The Theorem has three parts (Liebermann 1981). First, viewed solely as an economic problem, the placement of liability does not resolve into a question of discerning causation or blame.

The question [of liability] is commonly thought of as one in which $\mathrm{A}$ inflicts harm on B and what has to be decided is how should we restrain A? But this is wrong. We are dealing with a problem of a reciprocal nature. To avoid the harm to $B$ would inflict harm on $A$. The real question that has to be decided is: should A be allowed to harm B or should B be allowed to harm $A$ ? The real problem is to avoid the more serious harm (Coase 1960: 2).

Coase specifically rejects the placing of blame as an economic concept. With respect to cattle wandering onto a farmer's pasture, "there would be no crop damage without the cattle," but "there would be no crop damage without the crops." And concerning a confectioner whose noisy machines make a doctor's stethoscope useless, "[ $t]$ he doctor's work would not have been disturbed if the confectioner had not worked his machinery," yet "the machinery would have disturbed no one if the doctor had not set up his consulting room in that particular place." In sum, "[i]f we are to discuss the problem in terms of causation, both parties cause the damage (Ibid.: 13)."

Second, if transaction costs are zero (or sufficiently low), and if precedent places liability on the tortfeasor or leaves the victim unprotected, then the law of the case creates rights in either one party or the other, which the party owning the right can alienate (sell) to the other, to their mutual advantage. "[I]f such market transactions are costless, such a rearrangement of rights will always take place if it would lead to an increase in the value of production (Ibid.: 15)." 
Third, the resulting, eventual allocation of rights, absent disabling transaction costs, does not vary with the initial legal assignment of rights. Of course, one must "know whether the damaging business is liable or not for damage caused since without the establishment of this initial delimitation of rights there can be no market transactions to transfer and recombine them." Nevertheless, "the ultimate result (which maximises the value of production) is independent of the legal position if the pricing system is assumed to work without cost (lbid.: 8)."

The Coase Theorem, as a prediction about choice, seems reasonably unexceptionable: if we treat rights as commodities that people freely can buy and sell, then those rights will flow to their highest valued use. ${ }^{6}$ All else follows from Coase's insight that we can interpret rights as alienable. But Coase then goes on to consider the allocative consequences of legal rules if transaction costs restrict alienability. Here, courts must choose rules assigning rights as the parties themselves would reassign them if transaction costs had been low. Alternatively, courts must try to discern what action would have been chosen had the competing uses been under common ownership. That is, "[i]n a world in which there are costs of rearranging the rights established by the legal system, the courts, in cases relating to nuisance, are, in effect, making a decision on the economic problem and determining how resources are to be employed (Ibid.: 27)."

Coase's view of such cases suggests, "that the courts are conscious of this and they often make, although not always in a very explicit fashion, a comparison between what would be gained and what lost by preventing actions which have harmful effects (lbid.: 27f.)."

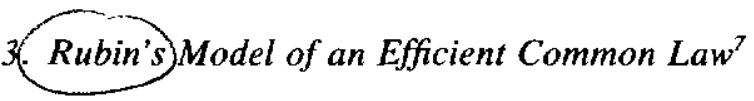

The recognition that common law rules have allocative consequences led research in two directions. The first involved a detailed examination of particular common law areas-contracts, torts, and property-and of specific rules within each area, to ascertain whether or not those

6 As a positive proposition, the Coase Theorem is not without its critics. See, e.g., Cooter (1982), who argues that non-cooperative behavior may scuttle appropriate bargains, and Aivazian and Callen (1981), who show that the core to the game with three or more people may be empty.

7 This section relies heavily on Aranson 1986. 
rules are efficient (see, e.g., Posner 1972a, 1972b, 1977). The second involved studies of the general common law process itself, to deduce conditions that lead to allocative efficiency (or otherwise).

Here, we consider this second direction. This research seeks to explain how courts might reach the efficient results that Coase and others claim to identify. That is, it involves the search for a mechanism, or set of institutional rules, which, given the participants' preferences, will lead to the adoption of allocatively efficient rules. The models thus purport to be positive. ${ }^{8}$

Rubin's (1977) model seeks such a mechanism. It goes beyond that of Coase, however, in that Coase (in the case of zero transaction costs) relies on "reasonably" uncomplicated bilateral bargaining to show that the final allocation of rights will be efficient. Rubin's model, by contrast, assumes explicitly that transaction costs prohibit bilateral or multilateral bargains; hence, in this respect it aptly describes ordinary accident cases but reveals a mechanism that nonetheless predicts legal evolution toward efficient rules.

Rubin considers a simple tort case in which a tortfeasor, $A$, and victim, $B$, initially face prohibitively high transaction costs. An accident occurs, which damages $B$ by an amount $X$. If the rule of liability favors $A$, then $B$ must absorb this cost. But if it favors $B$, then $A$ must pay $X$ to $B$. Suppose that the rule holds $A$ liable. His total $\operatorname{cost}, T_{A}$, is:

$$
T_{A}=S_{A}+N_{A}\left(S_{A}\right) X,
$$

8 There were at least two false starts in this literature. The first sought to explain the adoption of efficient rules in terms of judges' preferences alone. In this view the nineteenth century shift from strict liability in tort to a rule of negligence, say, emanated from judges who shared the class or economic interests of the firms whose owners benefited from this development (Horwitz 1977). That this shift was also (supposedly) efficient merely was the artifact of an unanticipated coincidence. Posner (1986: 233-8) examines and satisfactorily rejects this claim. Inter alia, it is not falsifiable because it is entirely tautological.

The second false start involves Posner's (1972b) own attempt to explain the adoption of efficient rules. Posner appears to claim that rules of judicial independence and procedure free judges from all other interests; so, if judges can do anything, they might as well adopt efficient rules to govern the resolution of disputes at common law. While this "lack-of-sufficient-reason" argument simply will not do (Epstein 1980), it contains enough of a motivational element to be falsifiable. And in my view (and that of many others), it has been falsified. See, e.g., Rubin 1982; Aranson 1985, 1988; Epstein 1985; Priest 1985; Rubin and Bailey 1992. 
where $S_{A}$ is $A$ 's optimal cost of accident-avoidance activities, and $N_{A}\left(S_{A}\right)$ is the expected number of future accidents if $A$ pays the avoidance cost of $S_{A}$. By assumption, only the party held liable takes avoidance measures. Thus, if he is "liable" (unable to receive compensation from $A$ ), then $B$ 's total cost, $T_{B}$, becomes:

$$
T_{B}=S_{B}+N_{B}\left(S_{B}\right) X .
$$

Efficiency requires liability to fall on the party whose total cost is lower. Thus, if $T_{A}$ is less than $T_{B}$, then an efficiency-seeking court will adopt a rule that holds $A$ liable. If the inequality is reversed, then the opposite result obtains. Rubin's model does not rely on judicial motivation. Instead, it depends solely on litigants' individual decisions to sue or settle. For example, suppose that an accident has occurred, in which $A$ has injured $B$, to the extent of $X$, that present law favors $B$ (holds $A$ liable), and that both $A$ and $B$ agree on the probability that $B$ will prevail at trial, $R$ ( $R$ exceeds one-half because precedent favors $B$ ). Furthermore, assume that a decision at trial against $B$ would shift liability entirely from $A$ to $B . A^{\prime} s$ and $B$ 's expected values of going to trial become, respectively,

$$
\begin{gathered}
V_{A}=R(-X)+(1-R) T_{A}-C, \\
V_{B}=R(X)+(I-R)\left(-T_{B}\right)-C,
\end{gathered}
$$

where $C$ represents the parties' equal court (litigation) costs.

If $-V_{A}$ exceeds $V_{B}$, then $A$ and $B$ will settle out of court. But if $V_{B}$ exceeds $-V_{A}$, then $A$ and $B$ will go to trial, which implies that

$$
(I-R)\left(T_{A}-T_{B}\right)>2 C \text {. }
$$

Notice that if $T_{B}$ exceeds $T_{A}$, then we could not satisfy this inequality, the rule would efficiently ${ }^{9}$ place liability on $A$, and the parties never would challenge it in court-they would always settle out of court. But for any $R$ less than one and finite $C$, if $T_{A}$ exceeds $T_{B}$, then the rule inefficiently has placed liability on $A$, and eventually some litigants will test it in court. Even if judges decide at random, the rule will be

$9 A$ and $B$ are placeholders for all similarly situated persons or firms. Rubin's claim that the common law process leads to the adoption of efficient rules depends crucially on the unstated assumption that there are equal numbers of similarly situated $A$ ' $s$ and $B$ ' $s$ and the stated assumption that their interests are symmetric. See Bailey 1991; Rubin and Bailey 1992. 
overturned in favor of an efficient liability placement that, for the reasons given, the parties never will test. In sum, over time the rule or precedent governing each general fact pattern will tend toward efficient placement of liability. This result holds whether courts establish a right de novo or reassign rights pursuant to changed economic conditions (for example, changes in accident or avoidance costs, or in avoidance technology).

Most writers refer to Rubin's model when they invoke "models of common law efficiency." But in the same essay Rubin also develops three other models, whose predictions vary from this one concerning efficiency. In the first model one party, but not the other, has a future interest in precedent. The rule then evolves to favor the party with the future interest, which only fortuitously might reflect efficiency. In the second model neither party has a future interest in precedent. If litigants agree on $R$, then they will settle out of court; otherwise they will go to trial, again with unpredictable results. In the third model the parties enjoy a continuing interest in precedent but can contract away from the rule's implications for avoidance placement, though not from its liability assignment. Such shifting never occurs if the rule is efficient, but it might occur if the rule is inefficient and if transaction costs are low. Here, the "price spread" affects the results exactly as it does in secondary markets under price discrimination in the primary markets; as transaction costs increase, eventually the model converges to the first one reviewed here.

Several other models appear in the literature, and these, together with Rubin's work, reveal a variety of assumptions and disparate findings concerning common law efficiency (Priest 1977; Goodman 1978; Landes and Posner 1979; Cooter and Kornhauser 1980; Terrebonne 1981). Combinations and permutations of assumptions within these models raise the possibility of millions of findings, only a few of which have been explored. The models to date thus remain profoundly inconclusive and incomplete with respect to common law efficiency. ${ }^{10}$

\section{The Calculation Problem}

\section{From Common Law to Central Planning}

In each area of common law-property, contracts, and torts-courts face a variety of decisions, each of which requires that they choose an

10 For recent analysis and commentary that casts doubt on efficiency claims, see Hadfield 1992, Bailey and Rubin 1992, Bailey 1991, and Johnston 1991. 
overarching rule. Property law, for example, concerns, inter alia, partly or completely incompatible uses. Courts, with such property cases before them, must choose injunctions, requiring nuisances to cease, or balance competing uses in the manner Coase describes. Contract law, inter alia, concerns breach. Courts, hearing such cases must choose specific performance, requiring parties to fulfill their promises, or the award of damages." Tort law, inter alia, concerns liability assignment when damage to person or property has occurred. Faced with such cases, courts must choose sirict liability, imposing costs on the person whose actions were the proximate cause of the damage, or a negligence test, requiring courts to balance avoidance measures against the likelihood and extent of damages. ${ }^{12}$

Injunctive relief in nuisance law gives plaintiffs the right to the quiet enjoyment of their property, notwithstanding the values of the activities that cause nuisances. Specific performance in contract law gives plaintiffs the right to secure actions that defendants have promised, notwithstanding defendants' costs of performance. Strict liability in tort law gives plaintiffs the right to compensation for injury to person or property, notwithstanding defendants' prior measures of care. These three rules, in short, dispense with calculation in favor of confirming plaintiffs" rights, "legitimate expectations" (Leoni 1992).

Judicial balancing in nuisance actions, by contrast, protects plaintiffs' property rights only if courts' calculated values of those rights exceed those of the activities from which nuisances issue. Damages following contractual breaches make plaintiffs' positions equal to what they would have been in the event of performance only if judges calculate accurately the values of performance. A negligence rule in tort compensates plaintiffs only if courts calculate that defendants have not taken an adequate measures of care.

11 The debate over reliance damages versus expectation damages in contract law is at least as significant as that over damages versus specific performance. I ignore the first debate here.

12 This account purposely oversimplifies the particular problems cited in each area of common law. For example, with respect to each problem one finds a host of defenses: "coming to the nuisance" in property law; impossibility, impracticability, and frustration of purpose in contract law; and contributory or comparative negligence in tort law. The discussion that follows applies to most of these issues as well as to the overarching questions. I also ignore in this section such issues as conveyance in property law, frustration in contract law, and intentional damage in tort law. 
The first three rules, in sum, do not rely on calculation to confirm people's rights. ${ }^{13}$ The last three rules do rely on calculation, in a manner that resembles the calculations found in central economic planning. Courts using the first three rules operate under the implicit assumption that a rights-preserving structure will minimize social opportunity costs. Courts using the last three rules operate under the explicit assumption that the judicial process can enter on a case-by-case basis, to get each matter right. It is in this sense that the calculation problem gains relevance for modern law and economics. ${ }^{14}$

\section{The Austrian and L.S.E. Critiques}

The Austrian and L.S.E. critiques offer four reasons to believe that courts, like central economic planners, cannot adequately perform the necessary calculations to get matters right. 1 call these reasons: (1) the computation problem; (2) the dynamic prediction problem; (3) the decentralized information problem; and (4) the subjective cost problem.

The computation problem. Both central economic planning and judging on wealth-maximizing or related utilitarian grounds supplant a price system with centralized, non-price direction. To get decisions right, therefore, both planners and courts must act as if they compute relative prices and estimate marginal utilities. The computation problem, however, exceeds human capacity. Mises (1948) and Hayek (1935a, 1935b) point out that under socialist central planning there exist no prices. Without prices there can be no economic calculation, to decide between competing resource uses. And:

Without calculation, economic activity is impossible. Since under Socialism economic calculation is impossible, under Socialism there can be no economic activity in our sense of the word. In small and insignificant things rational action might still persist. But, for the most part, it would

13 Most areas of common law contain irreducible requirements for calculation. Even with injunctive relief in nuisance law, for example, courts must calculate damages from the time the nuisance began until the time that the injunction takes effect. Specific performance may be impossible in contract law, or the parties may have contracted away from this remedy, in which case damages are required. Successful tort actions under a rule of strict liability also require assessments of damages. The argument here is not that calculation is wholly avoidable. Instead, I argue that courts can diminish the extent to which they rely on calculation, especially in the initial determination of liability. 14 I address the calculation problem with respect to constitutional law in Aranson, 1985, 1987, 1990. 
no longer be possible to speak of rational production. In the absence of criteria of rationality, production could not be consciously economical fo (Mises 1981: 119).

Private, decentralized calculation leads economteactors to economize on resource use, in much the same way as Rubin's autonomous process leads to the adoption of rules that place liability on lower-cost accident avoiders. But a central-planning agency cannot perform the calculations necessary to plan total economic activity or any significant part of it. Hayek (1940, 1948: 181f.) identifies the problem as one of an incredibly complex computation that defies human capacity, even for a small, static economy. A central-planning agency could not mimic market prices, and therefore it could not direct market allocations efficiently. Prices form imperfect measures of individual valuations, but even prices cannot be discerned in a satisfactory way.

Lost opportunities for economizing, and therefore waste, follow the abandonment of the price system. Hence, the Austrian identification of the (implicitly static) computation problem, along with its concentration on subjective valuation, shattered " $[t]$ he belief that socialism will dispense entirely with calculation in terms of value and will replace it with some sort of calculation in natura based on units of energy or of some other physical magnitude." And it had turned aside "the proposal that values, instead of being left to be determined by competition, should be found by a process of calculations carried out by the planning authority (Hayek 1940, 1948: 181)."

The dynamic prediction problem. Central-planning advocates (Lange 1938; Dickinson 1939) tried to overcome the Mises and Hayek objections based on the impossibility of computation by suggesting that the central authority could set prices and adjust them until markets cleared.

Hayek $(1937,1940,1948,1978)$ and later Kirzner $(1973,1979)$ observed in response that for the socialist theorists who advanced these proposals, prices were merely "parameters," and this "parametric function of prices" (Lange 1938: 70) casts each person solely as a price taker, who can do nothing to affect prices. This world is wholly static: all known technologies, factor or substitute availabilities, and methods of economic organization are given and immutable.

But prices are not merely "parameters" in a static system of known factors and technologies; prices are also nonparametric, endogenous variables in a dynamic economic system. Changes in relative prices 
(costs) set off unpredictable actions on entrepreneurial and other margins. Neither planners nor courts reliably can predict these actions and their consequences.

The socialist-pricing proposals led the Austrians to develop the concept of market process. Briefly stated, given any change in preferences or relative prices, a prior "equilibrium" would be upset. Prices, being nonparametric, are instead, exchange ratios subject to constant attack through a highly decentralized and rivalrous process, in which prices signal entrepreneurs to search for new profit opportunities that, when exploited, will themselves alter future prices (Kirzner 1973).

The socialist pricing scheme would impose on those subject to it either constant stagnation or constant dislocation because of the human engines of change. Let the central planners set initial prices. Ratios of marginal utility to price then change, as do those of marginal product to unit cost. Demand restructures, and so do the "proper" levels of relative prices. The authority has unleashed incalculable changes in the economy and must change prices again. In this activity it would seem no more effective than a dog pursuing its own tail (Hayek 1948: 187). ${ }^{15}$

The decentralized information problem. Relative prices and factor costs result from the more or less informed choices of actors throughout the economy. Knowledge of opportunities and individual preferences is broadly, even radically decentralized (Hayek 1945). To make plans centrally, or to render legal judgments based on the summary statistics that prices and quantities alone provide, remains difficult in a static economy. The successful pursuit of these activities becomes impossible in a dynamic economy.

Mises (1981) recognized that individual valuation and money price do not necessarily measure the same things. The first is decentralized,

15 Heiner, 1986, 1983, explains the posssible superiority of rule-governed decision making, as distinct from calculation, by appealing to a gap between the complexity of the environment and the decision maker's ability to understand it. We may interpret Heiner's work as an attempt to place a neoclassical foundation under Austrian ideas. Heiner's writing plainly corresponds to the computation problem. But it does not apply to the dynamic prediction problem. The reason for this lack of correspondence is that the decision problem in Heiner's work is wholly determined, and the remaining difficulty is one of estimation of underlying variables. But the decision problem is not so given under the dynamic prediction problem. That is precisely the meaning of the claim that prices are nonparametric. For a discussion of common law efficiency using reasoning very similar to Heiner's, see Hadfield 1992. 
subjective, and not interpersonally comparable. The second, while based on aggregate actions that reflect the first, merely indicates combined willingness to pay in a common denominator at a given moment in time, with respect to fixed technologies and factor availabilities.

Aggregated responses at a given moment in time, however, do not form sure predictions that these responses will remain in place or that there are predictable responses to changed conditions. Modest reductions in amount demanded, for example, may have accompanied past increases in a given factor's price. But only one or a few firms may be aware of the unheralded appearance of a new substitute. Quick emulation of those firms' actions in the face of a price increase might then lead to far more elastic demand. If knowledge of new substitutes is radically decentralized, planners' calculations, based on prior aggregations, may become wildly inaccurate.

The subjective cost problem. Costs remain subjective and not susceptible to ex post ascertainment and replicability. Planners, courts, and those who study these institutions, therefore, enjoy no sure basis for performing the calculations required to make or recommend decisions. A court in pursuit of efficiency or a scholar in search of evidence about precedential efficiency is seeking a chimera.

Subjective opportunity cost receives its fullest exploration in Buchanan's Cost and Choice (1969), which returns choice theory to L.S.E. roots. Buchanan distinguishes between real cost, or "choice-influencing cost," and neoclassical economic cost, or "choice-influenced cost." The first is the real, subjectively perceived opportunity cost (the loss of the best displaced alternative) that guides a decision maker at the penultimate moment of choice. It never can be subject to replication by an external observer. "Cost must be precisely dated in any theory of genuine choice because it is tied to the moment of choice as such. Before choice, cost exists as a subjective experience. After choice, cost vanishes in this sense (1969: 44)." "Objective cost," neoclassical cost, or "choice-influenced cost," by contrast, represents "consequences" that "are always realized after choice," and the chooser himself "may be considered a different person once the consequences of choice are realized (Ibid.: 48)."

The significance of this distinction between choice-influencing and choice-influenced costs for any external central-planning agency or for theoretical claims about the efficiency of public policies and legal rules remains telling. "The cost-benefit expert cannot have it both ways. $\mathrm{He}$ 
cannot claim 'scientific' precision for his estimates unless he restricts himself rigidly to objectively-observed magnitudes [choice-influenced costs]. But if he does this, he cannot claim that his estimates reflect reasonable norms upon which 'social' choices should be based (Ibid.: 60)."

The problem of public (judicial, legislative, or administrative) decision making then comes clearly into focus:

There is an obvious inconsistency. The Pigovian norm [for example] aims at bringing marginal private costs, as these infuence choice, into line with social costs, as these are objectively measured. Only with objective measurability can the proper corrective devices be introduced. But under what conditions can objectively measurable costs, external and internal, be taken to reflect, with reasonable accuracy, the costs that the effective decision maker may take into account (1969: 74)?

In a regime without prices, the equation of the two kinds of costs is an illusion based on an apparent similarity.

Since the persons who bear these "costs"- those who are externally affected-do not participate in the choice that generates the "costs," there is simply no means of determining, even indirectly, the value that they place on the utility loss that might be avoided (Ibid.: 72).

\section{Economic Calculation and Common Law Efficiency}

If calculation is a judicial chimera, wherein lies the common law's superiority, referred to at the outset? In earlier drafts of this and another paper (Aranson 1988), I conclude that the common law replaces the uncertainty of calculation with the certitude of doctrine, in the form of rule-governed choice. On this reading, "Austrian" judges would prefer strict liability to negligence, to govern decisions in tort actions; they would prefer injunctive remedies to a Coasian balance test in nuisance actions; and they would prefer specific performance over damages in matters of breach.

I continue to believe that a preference for bright-line rules over calculation is correct, ${ }^{16}$ but the justification for this preference only

16 Where courts choose the wrong body of law (e.g. tort law to govern contractual relations), negligence over strict liability may be preferred. For example, consequential damage to the plaintiff's property may grow out of a contractual nexus. The common law traditionally and in my view mistakenly, has treated such cases as torts, not as contract actions. In these circumstances a negligence rule ameliorates the underlying problem. Section IV takes up these problems at greater length. For a discussion of part of these legal rules, see Epstein, 1992. I am grateful to Richard Epstein for discussions about this problem. 
derivatively concerns the greater certainty that rule-governed choice achieves, important as it may be. Instead, rule-governed choice supports accurate preference revelation in subtle and ordinarily successful ways. Simply put, rule-governed choice returns present and future Notential) litigants' actions to a market or market-like context, where the information required for improved decision making and economic progress resides. The common law, as Rizzo (1980) says, is "institutionally efficient," because it returns decision making to the locus of superior informational competence.

The following discussion brings the calculation problem to bear on certain overarching choices in each area of common law. It describes at least one manner in which the calculation problem afflicts the calculation side of each choice and then turns to the superior preferencerevelation properties of a rights-based jurisprudence.

\section{Tort Law}

Negligence and the subjective cost problem. We return to Rubin's generic model of common (tort) law, to apply the subjective cost problem to it. Assume $A$ 's actions have damaged $B .{ }^{17}$ Rubin compares total costs, $T_{A}$ and $T_{B}$, to place liability on the party whose costs are lower. Consider the defendant's costs, $T_{A}$, which consist of two components, $S_{A}$, his total avoidance costs, and $N_{A}\left(S_{A}\right) X$, his expected liability costs of future accidents. $S_{A}$ appears in each component. But to find the value of $S_{A}$, the court must decide what avoidance costs the defendant faced at the penultimate moment of decision that caused the damage, which, by implication, it must then project into the future, to discern whether it would be reasonable to hold all such $A$ 's liable.

An application of subjective cost theory would fault this procedure on several grounds. First, the court cannot replicate $S_{A}$ itself, as it did or did not appear to the defendant. This cost, a subjective opportunity cost, only existed at the penultimate moment of choice, after which it

17 The structure of Rubin's model makes it applicable to any tort, property, or contract case in which transaction costs are high (and were so before the action complained of occurred) and his other assumptions hold. Hence, the discussion here is more general than the specific context in which Rubin framed his model. It is also important to observe that Rubin designed his model to be a prediction about litigants' choices based on their own information. Hence, it does not carry implications about a judges' (or our) ability to measure relevant costs as an external observer. Hence, our "use" of Rubin's model here goes well beyond his initial intentions. 
vanished forever (as did the "defendant" as the same person, for that matter). Hence, a "reasonable-man" standard, say, would remain without meaning or principle of application. Second, the defendant is unlikely to have been able to calculate costs as a guide for knowing what avoidance costs to incur or whether to defend or settle. $S_{A}$ in the first component is a choice-influencing cost, while $S_{A}$ in the second component, $N_{A}\left(S_{A}\right) X$, is a choice-influenced cost; there is no warrant for equating the two. Third, $X$ is a choice-influenced cost for $B$, a "social cost," but a choice-influencing cost for $A$ (by hypothesis).

Buchanan's formulation thus reveals the utter confusion in this casting of the problem, a confusion only compounded by the need to calculate similar costs, $T_{B}$, for the plaintiff, $B$. Rizzo, moreover, points out in the context of negligence deterninations, that some of these costs never existed at all as choice-influencing costs.

We are driven to compare two counterfactual hypotheses: If $A$ were required to bear the full social cost attached to his behavior he would have avoided the accident at $\left[\$ S_{A}\right]$, and if $B$ bore the full costs he would have avoided it at $\left[\$ S_{B}\right]$. Now if $\left[\$ S_{A}\right]$ is less than $\left[\$ S_{B}\right]$, the efficiency framework implies that $A$ ought to be made liable for the harm resulting from the accident. The issue is not to compare or evaluate what has happened but, rather, to speculate about what might have happened in two alternative worlds and then to compare the outcomes (1980a: 292).

This reliance on counterfactuals makes the court's problem that much more intractable. But this much we should have known. Any court that seeks to calculate such costs, and then to arrive at an "efficient" liability assignment, is engaged in a central planning, economic-calculation and direction activity. And so all of the Austrian and L.S.E critiques fully apply.

But let us assume, ex hypothesis, that a court somehow could overcome these problems and get the liability assignment right by a series of adjustments over time. Only if circumstances were fully static would the resulting rule enjoy a claim to efficiency. The problem here is precisely the same as the problem with the Lange-Dickinson socialistpricing proposal. At time $t=1$, the court "observes" costs and fashions a rule that, as precedent, will govern future similar parties' decisions. But at time $t=2$ conditions have changed, inter alia, because of the rule that the court enunciates at $t=1$, and those costs no longer remain relevant. The court then fashions a new rule, and so forth. As a consequence the court perpetually (and unsuccessfully) must "fight the last 
war" by forming judgments about future costs on the basis of earlier ones that no longer apply. ${ }^{18}$

The scholar's problem in seeking to discern efficiency merely replicates the court's in its assignment of liability based on negligence. No external observer could possibly make efficiency judgments that could command acceptance, given the Austrian-L.S.E. formulations of the problem. The costs that affect choice disappear at the instant of choice, and the common law's alleged flexibility under changing conditions would itself vitiate the reliability of any external observer's calculation. ${ }^{19}$

Negligence, strict liability, and preference revelation. Negligence rules do not wholly internalize the costs of actions that attend damage to persons or property. This claim may seem counterfactual, because if courts correctly apply a negligence standard, rational and globally knowledgeable defendants' levels of care converge with those found under common ownership. Courts, then, act as if internalizing pseudotransactions have occurred (De Alessi and Staaf 1989; Epstein 1973).

The subjective cost problem, however, as well as the other three problems that make up the calculation problem, alerts us that courts may not necessarily apply a negligence standard correctly. Hence, we cannot know if implicit internalizations of cost are correct. Stated in this manner, the problem with the application of negligence becomes identical to that of compensation in the classical tariffs case. KaldorHicks efficiency requires that, for an action to be efficient, in principle, gainers must be able to compensate losers and remain gainers. But because compensation remains a distributive question, not an allocative one, we need not require the actual payment of compensation.

That claim holds true only if external observers, here the courts, accurately can measure gains and losses. Where costs and benefits remain subjective, however, meaning that there can be no claim of

18 Landes and Posner, 1987: 123-31, observe that a "reasonable man" standard in negligence replaces individual relative cost determinations with average estimates. They justify this substitution on grounds of avoiding information costs. But if all costs of precaution are subjective, and if the dynamic prediction problem applies, then the substitution seems groundless. For a related discussion see supra note 17.

19 Claims of flexibility for the common law refer to its alleged ability to change course in the face of changing relative costs, technologies, and other social and economic developments. But the kind of rule-governed choice $I$ argue for here suggests a certain immutability to the common law. This theme is explored more carefully in Epstein 1980. 
accurate measurement, the only test of efficiency remains the requirement that compensation be paid (Buchanan 1959). A rule of strict liability in tort requires tortfeasors to compensate victims. And only through such a mechanism can one accurately reveal the parties' preferences.

The parallel between the application of strict liability in tort and the requirement that losers from government actions be compensated extends to a deeper level. Rizzo (1980) points out that strict liability allows for a test of the proposition that the activity forming the proximate cause of damage is indeed more valuable than the offsetting damage to person or property. The test reveals itself in the subsequent actions of the instant defendant and all future potential defendants. Similarly, Buchanan (1959) observes that the correct test for efficiency remains consent. The political economist's task is to create proposals for change, including compensations, that can gain the unanimous acceptance of affected parties.

\section{Contract Law}

Contract law is a "pure" variety of common law, because transaction costs do not necessarily preclude the alienation of obligations (liabilities) found within its body of precedents. Because contract law grows out of disputes arising from preexisting contracts, the parties might have contracted around extant rules, or reacted to their absence, though at some additional cost. To the extent that (1) obligations remain alienable, (2) parties know the law, and (3) transaction costs are negligible, the substance of contract rules does not matter. Parties may use preexisting rules or contract around them, as they see fit. This much follows from the Coase Theorem.

The goal of contract law is to help parties accomplish their joint purposes when their performances are temporally separated. It achieves this goal by two means. First, it provides certainty of performance of the promised conduct. Second, it incorporates rules that minimize (additional) transaction costs, by adopting conventions that most parties would adopt, most of the time, especially with respect to unforeseen contingencies.

Problems emerge when courts go beyond these means to modify contracts, fail to enforce their terms, including those that contract around legal conventions, or read into them provisions that they do not contain. The corpus of contract law is quite large, and I only 
consider a few doctrines here. But these doctrines are sufficiently central that applications of the calculation problem to them becomes apparent.

Contract formation. Courts may fail to enforce contracts whose initial formation they regard as sufficiently flawed. Reasons for doing so include coercion or duress, incapacity or incompetency, mutual mistake, misrepresentation and fraud or failure to disclose, and unconscionability. I consider the first and last of these here.

A release from performance because of coercion occurs in cases where the threat of physical force prevails at the time the parties form the contract. Scholars commonly explain this rule as preventing redistributions on the grounds that goods and services move to lower valued uses (Cooter and Ulen 1988: 249-56). Also, were the rule not to apply, parties would waste resources in making threats and in protecting against them.

But these efficiency-regarding explanations cannot suffice. Courts cannot know whether the alleged extortionist receives less utility from owning the involuntarily transferred good or service than does its original owner, nor can the relative values be measured in willingness-topay. This much should be clear from the subjective cost problem. Indeed, where hunger motivates coercion, the coercer may have been willing to pay enough to the victim to effect a sale, if only he had the funds.

The rule setting aside contracts coercively formed enjoys Austrian and L.S.E. credentials. The requirement that exchanges remain voluntary provides the only sure test of the proposition that the good or service is actually being transferred from a lower to a higher valued use. Such a rule performs the same function as does strict liability in tort law: it allows the experiment to take place that confirms the judgment of higher valued use.

A similar reasoning applies to "duress of goods," wherein the plaintiff has paid a sunk cost for some service, such as the repair of a television set. The defendant refuses to return the set in its original condition unless the plaintiff makes an additional payment that the original agreement did not contemplate. One might argue that if the plaintiff pays the additional charge, that he preferred to forego the money in return for the set; hence, the transaction was Pareto-improving. But the actual test is whether the plaintiff would have paid the original fee plus the additional charge ab initio. If not, then the market experiment without

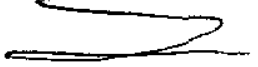


duress failed to prove that the transaction was welfare-regarding. Courts have no way to second-guess the relative values of the transaction under duress of goods; hence, ordinarily they will find for plaintiffs in such cases.

Contract-formation rules against coercion and duress excuse defendant's performance, but they constitute reasonably clear provisions that assure, ex ante, that the contract made the parties better off. This

- claim does not hold true of a more recent contract-formation doctrine, "unconscionability." Contract clauses are unconscionable if they

are so one-sided as to be unconscionable under the circumstances existing at the time of the making of the contract. . . The principle is one of the prevention of oppression and unfair surprise. . . and not of disturbance of allocation of risks because of superior bargaining power. ${ }^{20}$

Courts have used the doctrine to overturn a number of commercial practices, including add-on clauses, waiver-of-defense clauses, exclusion of liability for consequential damages, due-on-sale clauses, and termination-at-will clauses in franchise contracts. In each instance the deciding courts focus narrowly on each clause's effect on the instant litigants. And in all cases the courts ignore the effects on the litigants' class.

Add-on clauses, for example, allow merchants who sell under installment contracts, to reach as collateral goods that they previously sold the buyer. Courts have judged these clauses to be unconscionable, but as Epstein (1975) notes, they represent a least-cost way for poor people to acquire installment credit. Durables such as furniture lose value more rapidly than poor people can pay off installment loans, and the alternative for poor people would be higher down payments. Prior purchase from the same merchant also allows the merchant to assess the value of goods sold earlier. Add-on clauses, in sum, make credit available to some people who otherwise would not have it.

The reasons for enforcing these clauses go beyond simple appeals to freedom of contract. The problem is that the courts have no easy way to assemble the information required to assess their true effects. First, the judges who initially considered the issue were not even aware that add-on clauses might be welfare-regarding. Second, even if they

20 Uniform Commercial Code sec. 2-302 comment 1 (1977), as quoted in Cooter and Ulen 1988: 268. 
were so, it is not apparent that they would hold as dispositive detailed econometric studies to establish the demand and supply schedules for installment credit among a subgroup of the population; it is not even apparent that such studies easily could be done. Such courts, in short, would suffer from all four aspects of the calculation problem.

But markets for consumer durables and installment credit are competitive. Hence, these contract features likely provide the best possible arrangements for poor consumers. One would have to rely on a strong theory of consumer incompetence to set aside such agreements. That reliance, in turn, would require merchants to engage in different and difficult inquiries concerning their customers before issuing installment credit. $^{21}$

Performance excuses. Excuses from performance also involve contingencies that arise after the contract is formed. These include frustration (of purpose), impossibility, and commercial impracticability. Most treatments of these subjects in the law and economics literature frame the judicial question as efficient allocation of risk (see, e.g., Cooter and Ulen 1988: 277-81). Here, contract law has been only modestly more successful than in formation defenses, though not completely so, in avoiding calculation. Impracticability and frustration, however, hold the potential for becoming a mirror image of unconscionability, because courts must make ex post calculations of risk allocations and ascertain the value of partial performance. ${ }^{22}$

21 Criticisms of (unconscionability) rules against add-on clauses invoke all four parts of the Austrian and L.S.E. critiques. One useful way to restate the courts' calculation (information) problems is to observe that contract law grows out of disputes over failed contract terms, or at least contract terms under a cloud of legal challenge. Courts form the contours of contract law out of such material, but in doing so they tend to ignore the very large numbers of instances in which such contract terms work. Rulings about failed contract terms, nevertheless, govern the use of these terms in all future contracts, not just those that have failed. Hadfield, 1992, criticizes efficiency theories of common law processes on precisely this ground of selection bias. Even contract terms that give rise to disputes more often than not are addressed through alternative methods of dispute resolution (Macaulay 1963). I am indebted to William Camey for discussions of this idea.

22 See, e.g., Kull 1991, commenting on the expansive "gap-filling" role of courts where performance becomes difficult or costly, as suggested by Posner and Rosenfield (1977), Fried (1981), and as embodied in the notorious case of Aluminum Co. of Am. v. Essex Group, 499 F.Supp. 53 (W.D.Pa.1980). 


\section{P,}

Remedies. The principal remedies for breach in modern contract law involve the defendant's paying of compensatory damages.$^{23}$ Contracting parties sometimes may fashion their own damages, as part of the contracting process. These/include liquidated damage clauses, penalties, and specific performance. Courts, as a general rule, are least likely to enforce penalty ctauses and have created several exceptions to specific performance, somefimes failing to enforce it completely.

Any failure to enforce a contract as written reduces the parties' reliance on contracts as a manner of doing business; thus, such refusals limit freedom of contract itself. The Austrian and L.S.E. critiques hold implications for all such refusals.

De Alessi and Staff (1989) observe that courts ordinarily will award damages based on market prices for breach of contract. Ceteris paribus, this method accurately compensates plaintiffs for loss of marginal unit(s), as their marginal benefit for these units usually equals market price. But it does not compensate plaintiffs for inframarginal units. If perfect replacement of the performance contracted for is not possible, courts cannot accurately compensate plaintiffs. This condition will prevail where contract-specific performance is involved. But even where perfect substitutes are available, plaintiffs must undergo additional transactions.

When parties contract for their own remedies, not involving monetary compensation, one is likely to find complicated contract terms reflecting subjective values that monetary compensation cannot reach, else judicial compensation would be appropriate. But judicial reluctance to enforce such contract terms reduces the value of contracting (see relatedly Bishop 1985; Muris 1983; Schwartz 1979).

To restate the matter in terms of preference revelation, knowledge concerning the values of performance and nonperformance are subjectively known to plaintiff and defendant. The subjective-cost problem alerts us that courts cannot get these values right, and where the parties have contracted around compensatory damages to arrive at specific performance, or have specified damages in advance, courts should sustain these terms. Specific performance sends determination of the case back to the market, wherein resides the information required for judgment (Aranson 1988).

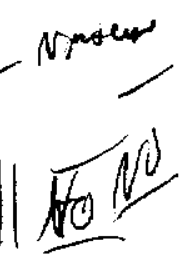

23 These include reliance damages, expectation damages, and damages associated with lost opportunities associated with the contract's formation.

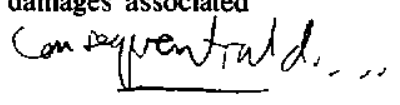




\section{Property Law}

Like contract law, property law covers a variety of subjects. I focus here on nuisance law, and the question whether courts should define nuisances based on property rights, which Epstein (1979) calls "corrective justice," or on comparative valuations of competing uses. The problem parallels that of strict liability versus negligence in the law of torts. ${ }^{24}$

Traditional nuisance law favors a nonutilitarian protection of property rights, and injunctive relief, along with damages paid for losses before the injunction issues. ${ }^{25}$ Coase's analysis (1960) favors a comparison of the values of competing uses, in the presence of high transactions costs. Indeed, as I note earlier, Coase eschews all appeals to causation, emphasizing instead the symmetrical roles of plaintiff and defendant. By this reading if defendant's activities are more valuable than plaintiff's, then no nuisance will be found.

As Epstein points out, however, Coase's analysis remains incomplete. For the Coase Theorem requires an initial assignment of rights. But what is the basis for that assignment, except a theory of property rights? "The weakness of the position is its failure to recognize that for legal purposes the question of causation can be resolved only after there is an acceptance of some initial distribution of rights (Epstein 1979: 58)."

The calculation problem afflicts all aspects of Coase's approach. If transaction costs are low, and if the action complained of falls within the traditional categories of recognized nuisances, then in a rightsbased system of law an injunction should issue. In a Coasian framework, however, the Court would first inquire whether the plaintiff's use of his property had greater value than the defendant's use of his. How is the Court to estimate the relative values in the instant case? Subjective

24 The matter is more than a parallel, in that nuisances are torts, and are studied as part of tort law.

25 Coase (1960) misstates the traditional rule because he focused on cases that set out some limited exceptions to it. For a review of traditional nuisance rules, see Epstein 1979. In repeating the old nuisance doctrine, "Le utility del chose excusera le noisomness del stink," Coase ignores the prevailing rule, "Sic utere tho ut alienum non laedas," "one may not use his property in a manner that injures another." But the injury must be to a legally recognized property right. See, e.g., Fountainbleau Hotel Corp. v. FortyFive Twenty-Five, Inc., 114 So.2d 357, 359 (1959). 
values abound in property valuations, and they become more pervasive still where livelihoods are involved.

Nor need we rely solely on subjective value to arrive at the same conclusion. The decentralized information problem remains at least as telling. Imagine, for example, a limit-pricing monopolist whose profits are very small, but whose plant produces factors for an important national industry. A much smaller firm might locate nearby and foul the air, making it impossible for the monopolist to operate. But when the court compares profits, it finds that the new firm is of higher value and thus declares that no nuisance has occurred. The monopolist goes out of business, because it cannot afford to buy out the new firm's activity. Some time passes before new entry, and losses to downstream firms become substantial.

If transaction costs are high, Coase's approach does not necessarily yield a superior solution. The major problem is that the court, if only implicitly, must estimate transaction costs if it wishes to extinguish prior property rights (create new easements) based on comparative valuations of uses. The most famous case in this line of reasoning, one that substituted damages for injunctive relief, is Boomer v. Atlantic Cement $\mathrm{Co}^{26}$ There the New York Court of Appeals refused to issue an injunction against a cement manufacturer that had damaged a residential area with a few low-level commercial establishments. The court read the case as involving air pollution, when in actuality the complaint went principally against the effects of blasting. The court evidently believed that the use of the traditional remedy would be unavailing, because of transaction (bargaining) costs. Against the possibility of holdouts, it balanced the $\$ 45$ million investment in the cement plant along with its substantial payroll. Farber (1988), however, has explored the record and found nothing remarkable in it to warrant treating Boomer differently from any other nuisance action.

Where transaction costs actually are high, in many cases there remains no reason for treating nuisances differently than one would treat other torts: strict liability should apply, not negligence. If that task exceeds the court's capacity, as it well may if large scale pollution problems are involved, then a legislative solution may be preferred. ${ }^{27}$

2626 N.Y.2d 919, 309 N.Y.2d 312, 275 N.E.2d 970 (1970).

27 The legislative forum must be tightly bound to the affected collectivity. Most solid waste and toxic tort problems are best handled by state and (preferably) local governments. Water pollution should be handled at the regional level. Most air pollution problems remain local in nature. See Aranson 1982. 
The goal of protecting against nuisances through "property rules" (Calabresi and Melamed 1972) is once again to foster revelation of preferences and information about cost. There remains a simple test of whether the source from which a nuisance issues is a more valued activity than the use to which the victim puts his property. That test is to issue an injunction, returning decision making to the market, to find out if the plaintiff will indeed allow the defendant to buy out his rights. Strict liability remains a second-best alternative where such transactions are indeed too costly.

\section{Rights, Calculation, and the Choice of Legal Rules}

The argument so far is that in traditional common law areas-property, contracts, and torts-courts enjoy two methods of decision making, one based on rights and the other on calculation. But like central economic planners, courts have not solved the calculation probtem, nor, for that matter, have those working in law and economics found a solution to this problem. Within each area of law, therefore, courts should prefer to come as close as they can to a rights-based jurisprudence. This method forces decisions back to a market relation, where the (radically decentralized and subjectively given) information obtains for making appropriate decisions.

From a broadened perspective, however, courts sometimes face the choice of which area of common law to assign particular cases. In this decision, too, the calculation problem arises. As a general rule, the use of contract law should trump the use of tort law whenever the action complained of arises from an explicit or implicit contractual relationship. Others have explained the reasons for this preference on neoclassical grounds (Coleman 1989; Danzon 1984; Epstein 1985; Havighurst 1986; Priest 1987; Rubin 1992). But this preference also responds to the limitations inherent in the calculation problem.

As a first approximation, tort law concerns relations among strangers, while contract law governs relations among acquaintances. The approximation never was complete, because tort law traditionally has covered damage to persons and property, even when the damage arises out of an explicit or implicit contractual nexus.

Damage resulting from medical malpractice and defective products, therefore, ordinarily may result in tort actions, not contract actions. 
In recent years, of course, courts have broadened the scope of malpractice and products liability (Priest 1985). Nineteenth century judges tried to soften the effects of tort law in such cases, by resorting to negligence instead of the then prevailing tort rule, strict liability. ${ }^{28}$ And defenses such as customary practice were often invoked (Epstein 1992). But courts now impose strict liability in many of these cases. Even where negligence rules prevail, it is an easy case for plaintiffs' attorneys to reach deep corporate pockets.

As various scholars have noted, the effect of assigning malpractice or enterprise liability cases to the category of torts effectively "bundles" an insurance policy with the primary good or service purchased (Rubin 1992). In traditional tort actions, those involving strangers, we preferred strict liability to negligence because under a negligence system neither the (potential) plaintiff nor defendant could know in advance the respective probability of harm or compensation or the appropriate care due. Nor, more importantly, could courts gain the information required to get matters right. In contract actions, though, we preferfed enforcement of contracts as written as well as injunctive relief, for similar reasons of informational accuracy. Each system-strict liability in tort and precise enforcement through injunctions in contractsappears best for its particular set of disputes.

But strict liability in tort is not equivalent to an unwincing contractual enforcement. Were it possible for strangers to contract with each other in advance, we might replace strict liability with the actual terms of the contract. And, the various parties might prefer the terms of the contract to strict liability.

In malpractice and product liability law cases, such contracts could emerge if courts would allow that result. The intellectual case against such an approach is a hollow shell, as Priest (1985) and Rubin (1992) observe. Terms such as "contract of adhesion" try to identify the takeit-or-leave-it nature of arrangements large firms would make "against" helpless, disorganized consumers.

The problem with this formulation is that the courts, through the imposition of tort liability to essentially contractual relations, have fashioned a new contract of adhesion, one in which consumers must purchase (costly) insurance bundled with the primary good or service, whether they want it or not. Stated differently, courts systematically

28 I am indebted to Richard Epstein for this observation. See supra note 16. 


\section{CONSTITUTIONAL POLITICAL ECONOMY}

avoid using markets to tap information about consumers' actual preferences.

The same problem afflicts a host of areas of law, including landlordtenant law (Rabin 1984) and labor law (Epstein 1984). Increasingly, one area of law after another falls into the category of torts. But the calculation problem remains, and for that reason the choice of a common law area is clear. Contract law should govern until it trembles under the load.

\section{REFERENCES}

Aivazian, V.A. and Callen, J.L. (1981) "The Coase Theorem and the Empty Core." Journal of Law and Economics 24: 175-81.

Aranson, P.H. (1982) "Pollution Control: The Case for Competition." In: R.W. Poole (ed) Instead of Regulation: Alternatives to the Federal Regulatory Agencies. Lexington, Mass.: D.C. Heath.

Aranson, P.H. (1985) "Judicial Control of the Political Branches: Public Purpose and Public Law." Cato Journal 4: 719-82.

Aranson, P.H. (1986) "Economic Efficiency and the Common Law: A Critical Survey." In: G. Skogh and J.M.G. von der Schulenberg (eds) Law and Economics and the Economics of Legal Regulation. Boston: Kluwer Academic Publishers.

Aranson, P.H. (1987) "Procedural and Substantive Constitutional Protections of Economic Liberty." Cato Journal 7: 345-75.

Aranson, P.H. (1988) "Bruno Leoni in Retrospect." Harvard Journal of Law and Public Policy 11: 661-711.

Aranson, P.H. (1990) "Models of Judicial Choice as Allocation and Distribution in Constitutional Law." Brigham Young University Law Review 1990: 745-827.

Aranson, P.H., and Ordeshook, P.C. (1981) "Regulation, Redistribution, and Public Choice." Public Choice 37: 69-100.

Aranson, P.H., and Ordeshook, P.C. (1985) "Public Interest, Private Interest, and the Democratic Polity." In: R. Benjamin and S. Elkin (eds) The Democratic State. Lawrence: University Press of Kansas.

Bailey, M.J. (1991) "Selective Litigation Pressure on Court-Made Law." Emory University Department of Economics Working Paper.

Bishop, W. (1985) "The Choice of Remedy for Breach of Contract." Journal of Legal Studies 14: 299-320.

Brown, J.P. (1973) "Toward an Economic Theory of Liability." Journal of Legal Studies 2: 323-49.

Buchanan, J.M. (1950) "Positive Economics, Welfare Economics, and Political Economy." Journal of Law and Economics 2: 124-38.

Buchanan, J.M. (1969) Cost and Choice. Chicago: Markham.

Calabresi, G., and Melamed, D.A. (1972) "Property Rules, Liability Rules, and Inalienability: One View of the Cathedral." Harvard Law Review 85: 1089-128. 


\section{THE COMMON LAW AS CENTRAL ECONOMIC PLANNING}

Coase, R.H. (1960) "The Problem of Social Cost." Journal of Law and Economics 3: 1-44.

Coleman, J.L. (1989) "A Market Approach to Products Liability Reform." St. Louis: Center for the Study of American Business.

Cooter, R. (1982) "The Cost of Coase." Journal of Legal Studies 11: 1-33.

Cooter, R., and Kornhauser, L. (1980) "Can Litigation Improve the Law without the Help of Judges?" Journal of Legal Studies 9: 139-63.

Cooter, R., and Ulen, T. (1988) Law and Economics. Harper Collins.

Danzon, P. (1984) "Tort Reform and the Role of Government in Private Insurance Markets." Journal of Legal Studies 13: 517-50.

De Alessi, L., and Staaf, R.J. (1989) "Subjective Value in Contract Law." Journal of Institutional and Theoretical Economics 145: 561-77.

Demsetz, H. (1964) "The Exchange and Enforcement of Property Rights." Journal of Law and Economics 7: 11-26.

Demsetz, H. (1967) "Toward a Theory of Property Rights." American Economic Review Papers and Proceedings 57: 347-59.

Dickinson, H.D. (1939) Economics of Socialism. London: Oxford University Press.

Epstein, R.A. (1973) "A Theory of Strict Liability." Journal of Legal Studies 2: 151-204.

Epstein, R.A. (1975) "Unconscionability: A Critical Reappraisal." Journal of Law and Economics 18: 293-315.

Epstein, R.A. (1979) "Nuisance Law: Corrective Justice and Its Utilitarian Constraints." Journal of Legal Studies 8: 49-102.

Epstein, R.A. (1980) "The Static Conception of the Common Law." Journal of Legal Studies 9: 253-75.

Epstein, R.A. (1982a) "The Social Consequences of Common Law Rules." Harvard Law Review 95: 1717-51.

Epstein, R.A. (1982b) "Taxation, Regulation, and Confiscation." Osgoode Hall Law Journal 20: 433-53.

Epstein, R.A. (1984) "In Defense of Contract at Will." University of Chicago Law Review 51: 947-82.

Epstein, R.A. (1985) "Products Liability as an Insurance Market." Journal of Legal Studies 14: 645-70.

Epstein, R.A. (1992) "The.Path to The T.J. Hooper: The Theory and History of Custom in the Law of Tort." Journal of Legal Studies 21: 1-38.

Farber, D.A. (1988) "Reassessing Boomer: Justice, Efficiency, and Nuisance Law." In: P.H. Hay and M.H. Hoeflich (eds) Property Law and Legal Education: Essays in Honor of John E. Cribbet. Urbana: University of Illinois Press.

Fried, C. (1981) Contract as Promise: A Theory of Contractual Obligation. Harvard University Press.

Goodman, J.C. (1978) "An Economic Theory of the Evolution of the Common Law." Journal of Legal Studies 7: 393-406.

Hadfield, G.K. (1992) "Bias in the Evolution of Legal Rules." Georgetown Law Journal 80: 583-616.

Havighurst, C.C. (1986) "Private Reform of Tort-Law Dogma: Market Opportunities and Legal Obstacles." Law and Contemporary Problems 49: 143-72.

Hayek, F.A. (ed) (1935) Collectivist Economic Planning. London: Routledge. 
Hayek, F.A. (1937) "Economics and Knowledge." Economica 4: 33-54.

Hayek, F.A. (1940) "Socialist Calculation: The Competitive 'Solution.'" Economica 7: 125-49.

Hayek, F.A. (1945) "The Use of Knowledge in Society." American Economic Review 35: 519-30.

Hayek, F.A. (1948) Individualism and Economic Order. Chicago: University of Chicago Press.

Hayek, F.A. (1978) "Competition as a Discovery Process." In: F.A. Hayek (ed) New Studies in Politics, Economics, and the History of Ideas. Chicago: University of Chicago Press.

Heiner, R.A. (1983) "The Origins of Predictable Behavior." American Economic Review 73: 560-95.

Heiner, R.A. (1986) "Imperfect Decisions and the Law: On the Evolution of Legal Precedent and Rules." Journal of Legal Studies 15: 227-61.

Horwitz, M.J. (1977) The Transformation of American Law. Cambridge: Harvard University Press.

Johnston, J.S. (1991) "Uncertainty, Chaos, and the Torts Process: An Economic Analysis . of Legal Form." Cornell Law Review 76: 341-400.

Kirzner, I.M. (1973) Competition and Entrepreneurship. Chicago: University of Chicago Press.

Kirzner, I.M. (1979) Perception, Opportunity, and Profit. Chicago: University of Chicago Press.

Kirzner, I.M. (1985) Discovery and the Capitalist Process. Chicago: University of Chicago Press.

Kull, A. (1991) "Mistake, Frustration, and the Windfall Principle of Contract Remedies." Hastings Law Journal 43: 1-55.

Landes, W.M., and Posner, R.A. (1979) "Adjudication as a Private Good." Journal of Legal Studies 8: 235-84.

Landes, W.M., and Posner, R.A. (1987) The Economic Structure of Tort Law. Cambridge: Harvard University Press.

Lange, O. (1938) "On the Economic Theory of Socialism." In: B. Lippincott (ed) On the Economic Theory of Socialism. Minneapolis: University of Minnesota Press.

Leoni, B. (1992) Freedom and the Law. 3rd ed. Indianapolis: Liberty Classic.

Liebermann, Y. (1981) "The Coase Theorem in Jewish Law." Journal of Legal Studies 10: 293-303.

Lowi, T.J. (1979) The End of Liberalism. 2nd ed. New York: Norton.

Macaulay, S. (1963) "Non-contractual Relations in Business: A Preliminary Study." American Sociological Review 28: 55-67.

McChesney, F.S. (1991) "Antitrust and Regulation: Chicago's Contradictory Views." Cato Journal 10: 775-98.

Mises, L. von (1981) Socialism: An Economic and Sociological Analysis. Indianapolis: Liberty Classic.

Muris, T.J. (1983) "Cost of Completion or Diminution in Market Value: The Relevance of Subjective Value." Journal of Legal Studies 12: 379-400.

O'Driscoll, G.P., Jr. (1980) "Justice, Efficiency, and the Economic Analysis of Law: A Comment on Fried." Journal of Legal Studies 9: 355-66. 


\section{THE COMMON LAW AS CENTRAL ECONOMIC PLANNING}

Peltzman, S. (1976) "Toward a More General Theory of Regulation." Journal of Law and Economics 19: 211-40.

Posner, R.A. (1971) “Taxation by Regulation." Bell Journal of Economics and Management Science 2: 22-50.

Posner, R.A. (1972a) "A Theory of Negligence." Journal of Legal Studies 1: 29-96.

Posner, R.A. (1972b) Economic Analysis of Law. 1st ed. Boston: Little, Brown.

Posner, R.A. (1974) "Theories of Economic Regulation." Bell Journal of Economics and Management Science 5: 335-58.

Posner, R.A. (1986) Economic Analysis of Law. 3rd ed. Boston: Little, Brown.

Posner, R.A., and Rosenfield, A.M. (1977) "Impossibility and Related Doctrines in Contract Law." Journal of Legal Studies 6: 83-117.

Priest, G.L. (1977) "The Common Law Process and the Selection of Efficient Rules." Journal of Legal Studies 6: 65-82.

Priest, G.L. (1985) "The Invention of Enterprise Liability: A Critical History of the Intellectual Foundations of Modern Tort Law." Journal of Legal Studies 6: 461-528.

Priest, G.L. (1987) "The Current Insurance Crisis and Modern Tort Law." Yale Law Journal 96: 1521-90.

Prosser, W.L. (1955) The Law of Torts. 2nd ed.

Rabin, E.H. (1984) "The Revolution in Residential Landlord Tenant Law: Causes and Consequences." Cornell Law Review 69: 517-84.

Rizzo, M.J. (1980a) "Law Amid Flux: The Economics of Negligence and Strict Liability in Tort." Journal of Legal Studies 9: 291-318.

Rizzo, M.J. (1980b) "The Mirage of Efficiency." Hofstra Law Review 8: 641-58.

Rizzo, M.J. (1985) "Rules versus Cost-Benefit Analysis in the Common Law." Cato Journal 4: 865-85.

Rubin, P.H. (1977) "Why is the Common Law Efficient?" Journal of Legal Studies 6: 51-63.

Rubin, P.H. (1982) "Common Law and Statute Law." Journal of Legal Studies 11: 205-23.

Rubin, P.H. (1992) “Tort Reform by Contract." Emory University Department of Economics Working Paper.

Rubin, P.H., and Bailey, M.J. (1992) "A Positive Theory of Legal Change." Emory University Department of Economics Working Paper.

Schwartz, A. (1979) "The Case for Specific Performance." Yale Law Journal 89: 271-306.

Shavell, S. (1980) "Strict Liability versus Negligence." Journal of Legal Studies 9: $1-25$.

Stigler, G.J. (1971) "The Theory of Economic Regulation." Bell Journal of Economics and Management Science 2: 3-21.

Terrebonne, R.P. (1981) "A Strictly Evolutionary Model of Common Law." Journal of Legal Studies 11: 397-407.

Tullock, G. (1967) "The Welfare Costs of Tariffs, Monopoly, and Theft." Western Economic Journal 5: 224-32. 